\title{
The Management of Parental Involvement in Multicultural Schools in South Africa: A Case Study
}

Sathiapama Michael ${ }^{1}$, Charl C. Wolhuter ${ }^{\star 2}$ ANd Noleen van WyK ${ }^{3}$

$\approx$ The aim of this study was to investigate the management of parental involvement in three multicultural schools in the Umlazi District in Durban, South Africa. A literature survey resulting in a theoretical framework on parental involvement in schools, multicultural schools, and the managing of parental involvement in schools has been done. The contextual background of schools in contemporary South Africa is depicted. A qualitative research design has been used. Focus group discussions have been conducted, with a total of thirty-three principals, teachers and parents. It has found that there is a low level of meaningful contact between school and parents. Apathy exists on the side of parents, low expectations on the side of principals and teachers, and an organisational structure facilitating parent-school interaction is lacking. In managing parental involvement in multicultural schools, school managers display a lack of intercultural sensitivity.

Keywords: Multicultural schools, Parent involvement, Qualitative research, School Management, South African case study

1 Postgraduate student: Department of Educational Studies, University of South Africa, South Africa

sarasmichael@yahoo.com

$2 \quad{ }^{*}$ Corresponding author. North-West University, Potchefstroom, South Africa charl.wolhuter@nwu.ac.za

3 University of South Africa, South Africa noleen.vw@vodamail.co.za 


\section{Menedžment vključevanja staršev v multikulturne šole v Južnoafriški republiki: študija primera}

Sathiapama Michael, Charl C. Wolhuter ${ }^{\star}$ in Noleen van Wyk

$\propto$ Namen študije je raziskati menedžment vključevanja staršev v tri multikulturne šole v okrožju Umlazi v mestu Durban v Južnoafriški republiki. $\mathrm{Na}$ osnovi pregleda literature so bila oblikovana teoretična izhodišča glede vključevanja staršev v šole, multikulturnih šol in menedžmenta vključevanja staršev v šole. Predstavljeno je kontekstualno ozadje šol v sodobni Južnoafriški republiki. Uporabljen je bil kvalitativni raziskovalni pristop. Izvedena je bila diskusija v fokusnih skupinah s skupno triintridesetimi ravnatelji, učitelji in starši. Ugotovljena je bila nizka raven pomembnih stikov med šolo in starši. Na strani staršev gre za apatijo, na strani ravnateljev in učiteljev pa za nizka pričakovanja, manjka tudi organizacijska struktura, ki bi olajšala interakcijo med starši in šolo. Pri organiziranju vključevanja staršev v multikulturnih šolah vodstva šol kažejo na pomanjkanje medkulturne senzitivnosti.

Ključne besede: vključevanje staršev, šolski menedžment, multikulturne šole, kvalitativna raziskava, Južnoafriška republika - študija primera 


\section{Introduction}

The benefits of parent-teacher co-operation are strongly supported by research, which has now taken place over a number of decades (cf. Henderson \& Mapp 2002). As a result of this research, it is widely accepted that good family-school partnerships lead to improved academic student achievement, selfesteem, school attendance and social behaviour, a reduction in school drop-out rates, more positive parent-child communication; and improved school programmes and school climate (Banks \& Banks, 1997, p. 409; Chavkin, 1993, p. 276; Epstein, 1995a, p. 701; Hester, 1989, p. 23; Jones \& Blendinger, 1994, p. 80; Lemmer, 2000, p. 61; Squelch \& Lemmer, 1994, p. 13; Van Wyk \& Lemmer, 2009, pp. 16-17). Furthermore, research shows that these benefits occur irrespective of the socio-economic class to which the family belongs (cf. Haberman 1992). Likewise, teachers who frequently involve families in their children's education rate single and married parents, and more and less educated parents, as equally helpful with their children at home when shown how to be so (Epstein \& Sanders 2000, p. 289). Considering these benefits, family-school relationships assume special significance in a country such as South Africa, where (as is commonly the case in developing countries) large parts of the school system are dysfunctional (cf. Wolhuter, 2007, 2011). The aim of this article is to investigate the management of parental involvement in schools in one district in South Africa. Another dimension that has been added is that this has been done within diverse school communities as schools in South Africa have recently been desegregated: a radical reversal of the historical pattern of racially segregated schooling. The new socio-cultural dynamics and context, and the increasing importance of education in multicultural societies worldwide, give this study increased relevance.

This article commences with a literature survey and theoretical framework on multicultural education, parental involvement in schools, and the management of parental involvement in schools. The contextual background of schools in contemporary South Africa is then depicted. That is followed by an explanation of the research methodology and a presentation and discussion of the findings.

\section{Literature survey}

\section{Parental involvement in education}

The unique circumstances of each school determine how parental involvement should be planned at that school (Botha, 2000, p. 14). Ravn (2003, 
p. 9) agrees, adding that cultural contexts of countries impact the interplay between parents and schools. This means that, in general, there is no 'one perfect' parental involvement program. In spite of this, Lemmer (2007, p. 278) stated that effective partnership models demonstrate certain common themes:

- $\quad$ Effective partnership models are school based and school driven;

- $\quad$ They conceptualise the family and community very broadly and flexibly;

- $\quad$ Effective partnership models allow for a continuum of involvement: from complex school-based activities (such as assisting in the classroom) to simpler home-based activities (such as monitoring children's homework activities or simply covering books available at the school library);

- Effective partnership models form part of a school improvement plan linked to specific outcomes.

In addition to these common themes, Williams and Chavkin (1989, pp. 18-20) stated that the following seven elements should be an integral part of parental involvement programs:

- $\quad$ written policies that specify areas for parent involvement;

- $\quad$ administrative support (resources such as a meeting venue and duplicating facilities, funds and personnel);

- continuous training of teachers and of parents in elements of parent involvement;

- $\quad$ partnership approaches in curricular, management and non-curricular matters, which help parents and teachers develop an attitude of ownership towards the school and take pride in it;

- two-way communication, i.e. regular communication between parents and school, e.g. newsletters, personal visits and telephone calls should exist;

- liaisons with the school with regard to parental involvement programs, helping participants to benefit from each others' experiences;

- continuous evaluation of the school's parent evaluation programme.

Van der Linde (1997, p. 40) adapted Bastiani's model (1996) to suit the South African school situation, and recommended it as an effective model for multicultural schools. Van der Linde specified the following nine areas for developing school-home links:

- communication of information;

- arrangements to discuss problems of individual children, involving parents in their children's learning, and helping with the running of the school; 
- developing interest in, understanding of and support for the work of the school;

- $\quad$ use of parental skills, interests and experience;

- $\quad$ providing opportunities for parents' own education and development;

- $\quad$ enlisting parents' views in decision-making policy; active involvement with, and support for, family and community life.

One model that fulfils these criteria and that is used throughout the world was developed by Joyce Epstein. In the 1980s, Epstein developed a theoretical perspective called 'overlapping spheres of influence' that posited that the most effective families have overlapping shared goals and missions concerning children (Epstein, 1995b, p. 214). The model recognised that the three major contexts in which children learn and grow - the family, school and community - could be drawn together or pushed apart. Epstein (2001, pp. 408-410) described six types of family-school-community involvement falling within the areas of overlapping spheres.

Type 1 Epstein terms Parenting. The school helps families to support children as learners through workshops and meetings.

Type 2 is Communicating and includes printed and non-printed communications, taking into account parents who do not speak English (or whatever is the language of school administration) or who are illiterate. It should also be kept in mind that parents' language difficulties could result in them not understanding the participation opportunities given to them, which often leads to teachers labelling such parents as 'uninterested' (Van Wyk, 2010, p. 217). Possible means of communicating with parents include letters, written reports/profiles, parent evenings and home visitation.

Type 3 Volunteering, refers to anyone assisting with children's learning or development in any way, at any time and place. Flexible schedules should be made for volunteers, allowing those who work to participate.

Type 4 Learning at home, entails the provision of information and ideas to families about how to help students with homework and other curriculumrelated activities, decisions and planning. Garca-Lubeck (as quoted by Chavkin, 1989, p. 282) emphasises that minority parents (i.e. those from a cultural background other than the culture upon which the school 
organisation is based) should be assisted to understand the school calendar, school schedule, staff roles, attendance rules, course requirements, benefits and responsibilities of extracurricular activities, homework policy and requirements for holiday and closing of the school.

Type 5 Decision-making is the process of partnership, view-sharing and action towards shared views.

Type 6 Collaborating with the community, means identifying and integrating resources and co-services from the community to strengthen school programs and student learning and development.

Epstein (1995a, p. 707) asserted that the six types of involvement could guide the development of a balanced, comprehensive program of partnership, with potentially important results for students, parents and teachers.

\section{Multicultural schools}

Many countries in the world have become more heterogeneous as a result of various social, economic and political developments (Nkomo, Chisholm, \& McKinney, 2004, p. 4). This is also reflected in schools where learners from different racial and ethnic backgrounds, speaking different languages now increasingly have to be accommodated (cf. Meier, Lemmer, \& Van Wyk, 2006). These differences, coupled with a global focus on human rights and equal educational opportunities, mean that most schools are looking for ways of educating a diverse learner population equally or equitably. Mda (1999, p. 219) described the diversity of classrooms as socially, linguistically, and economically diverse. Moreover, learners in school classrooms have striking differences in family structures, lifestyle, health, and physical and mental abilities. This is the reality that many teachers in South Africa and elsewhere in the world have to face. One approach is for the school to adopt a multicultural approach to education.

Multicultural education is a multidimensional educational approach according equal recognition to all cultural groups and providing all learners with a meaningful and relevant educational experience. The ideal of multiculturalism involves achieving a positive sense of self-worth in a person's own culture while not diminishing or derogating any other cultural forms. It involves pride in one's own culture along with tolerance, contact and sharing with the other: in other words, a thoroughly unprejudiced approach to people is needed (Sampson, 1999, p. 207). After decades of separation between racial and ethnic groups in South Africa, many see multicultural education as one of the ways 
in which understanding and acceptance of all races and cultures in the country can be improved (Sleeter \& Grant, 2007; p. 150). This is reinforced by the fact that multicultural education seeks to promote equal educational opportunities, the preservation of cultural identity, the value of human dignity and self-esteem, and the peaceful co-existence of diverse lifestyles (Castagno, 2009, p. 43; Squelch, 1996, p. 61). Embedded in multicultural education is a need for sound working relationships between families, schools and communities. In addition, the benefits of effective home-school relationships, as previously discussed, show that parent-teacher collaboration will maximise all learners' chances of progressing in school. Given the dissonance between the cultural background of minority parents and that of the school as organisation, effective parental involvement in a multicultural school is infinitely more complex than at a mono-cultural school.

\section{Managing parental involvement}

Parental involvement is regarded as an integral management area in school management. The challenge in achieving effective parental involvement lies with the principal whose responsibility it is to assure and facilitate the extent of parental involvement (Pearson, 1990, p. 15). This is important as research has shown that the policy and practice of parental involvement as determined by school management is of greater importance than family background variables, such as race, ethnicity, socioeconomic level or marital status in determining the extent of parental involvement in children's education (Epstein \& Sanders, 2000, p. 289).

\section{South African context}

In 2007, the population of South Africa was 47.9 million, of which $79.6 \%$ were Africans, 9.6\% white, $8.9 \%$ people of mixed racial decent (Commonly referred to as 'Coloureds') and 2.5\% Indian/Asian (OECD, 2008, pp. 28-29).

Socio-economic disparities are rife, and often relate to the racial divide within the country: Whites are the most affluent, Blacks the poorest, Indians and people of mixed race somewhere in between. For centuries, the education system of South Africa was characterised by rigid segregation. White schools were, measured by physical resources, teachers' qualifications, learner achievement levels and the like, orders of magnitude better than the Black schools (cf. Wolhuter, 1998). One of the causes of the socio-political turmoil in the years before 1994 was the unequal education system. After the dawn of the new political order in 1994, the education system was redesigned. One of the features of the post-1994 education has been desegregation. However, desegregation has 
been very much a one-way process, i.e. of Black students moving from the Black schools to the better endowed Coloured (mixed race), Indian and White schools, students of mixed race to the Indian and White schools, and Indian students to the White schools, giving the historically Mixed race, Indian and White schools (which will be the focus of this article) a multicultural character. In many South African schools, assimilation remains the dominant model of integration, which means that the values, traditions and customs of the dominant group frame the social and cultural contexts of the school (Soudien, 2004, p. 93).

\section{Research questions}

In the light of the above, the following objectives for this study may be identified:

- Which factors impinge on effective involvement at multicultural South African schools?

- What role is management playing in parental involvement in multicultural South African schools?

- How can these findings contribute to the effective management of parental involvement in multicultural South African schools?

\section{Research method}

A qualitative research design was employed. Since in the 1970s, qualitative research methods have aroused the interest of educational researchers as a valid and useful method, thus resulting in a proliferation of qualitative studies of educational settings and problems (Lemmer, 1992, p. 292). Qualitative research methodology involves documenting real events, recording what people say (with words, gestures and tone) observing specific behaviours, or examining visual images (Neumann, 1999, p. 320). Qualitative research is research that elicits research participants' accounts of meanings, experiences or perceptions. Thus, qualitative research seeks to explore and explain phenomena from the perspectives of those who are studied (Smit, 2010, p. 35). It also produces descriptive data in the participants' own written or spoken words. It therefore involves identifying the participants' beliefs and values that underlie the phenomena (Bogdan \& Biklen, 1992, p. 2; De Vos, 1998, p. 243; Lemmer, 1992, p. 293). This case study used a qualitative research design to attempt to understand how school managers, parents and school governing body members experience the management of parental involvement in multicultural schools in particular. As such, the study fulfils the criteria of case studies in that it attempts an in-depth 
analysis and understanding of the research phenomena (Smit, 2010, p. 36).

The qualitative research method of focus groups was employed. Interviewing focus groups can be defined as a group discussion in which a small number of participants, typically six to twelve, talk about topics of special relevance to a study, under the guidance of a moderator (Hoberg, 1999, p. 136). According to Cohen and Manion (2000, p. 288), focus groups differ from group interviews, which are characterised by communication between interviewer and group members. In addition, focus groups rely on the interaction between group members. Schumacher and McMillan (1997, p. 453) maintain that by creating a social environment in which group members are stimulated by the perceptions and ideas of each other, the quality and richness of the data obtained would exceed that of data procured by mere interviewing.

Three focus groups involving three schools were constituted. The first focus group included three members of the management team (principal and two teachers of the school management team) of each school, i.e., nine members. The focus group discussion schedule for the school management teams appear in Appendix 1. The second focus group consisted of three member (parents) serving on the school governing body of each school, i.e. also nine members. The focus group discussion schedule for school governing body members appear in Appendix 2. The third focus group was a focus group with parents (who were not members of school governing bodies). Five parents from each of the three schools were involved, i.e. fifteen parents. The focus group discussion schedule for parents appears in Appendix 3. Thus, in total 33 participants were included in the research.

The socio-graphical profile of the focus group participants appear in Table 1.

Table 1: Socio-graphical profile of focus group participants

\begin{tabular}{|l|c|c|c|}
\hline & $\begin{array}{c}\text { Management teams } \\
\text { from schools A, B \& C }\end{array}$ & $\begin{array}{c}\text { School governing bodies } \\
\text { from schools A, B \& C }\end{array}$ & $\begin{array}{c}\text { Parents from schools } \\
\text { A, B \& C }\end{array}$ \\
\hline White participants & 2 & 1 & 1 \\
\hline Indian participants & 7 & 7 & 8 \\
\hline People of mixed race & 0 & 0 & 5 \\
\hline Black participants & 0 & 1 & 3 \\
\hline Male & 5 & 5 & 12 \\
\hline Female & 4 & 4 & 1 \\
\hline
\end{tabular}

Following the collection of data, the data was coded. This meant that every theme, concept, interpretation, typology and proposition identified was 
coded according to the standard procedures of analysing data collected in qualitative research. The coded data was then clustered into categories, which can later be developed into themes (Smit, 2010, p. 37).

\section{Conclusions}

\section{School settings}

The three schools involved in the study are secondary schools ${ }^{4}$ in the Umlazi district, which is part of the greater Durban metropolis. It is a part of the country with a large concentration of Indians, although Blacks and Whites do also reside in the area. The language of learning and teaching in all three schools is English. Some characteristics of the three schools are presented in Table 2.

Table 2: Characteristics of the three schools involved in the study

\begin{tabular}{|l|r|r|r|}
\hline Characteristic & School A & School B & School C \\
\hline Total number of students & 1179 & 1136 & 1075 \\
\hline Number of students per population group & \multicolumn{3}{|c|}{} \\
\hline - Black & 500 & 352 & 336 \\
\hline - Indian & 662 & 774 & 270 \\
\hline - People of mixed race & 17 & 10 & 42 \\
\hline - White & 0 & 0 & 427 \\
\hline Number of students per home language * & & & \\
\hline - English & 684 & 787 & 728 \\
\hline - Afrikaans & 13 & 1 & 20 \\
\hline - Isixhosa & 3 & 11 & 17 \\
\hline - Siswati & 472 & 2 & 1 \\
\hline - Isizulu & 5 & 331 & 304 \\
\hline - Sesotho & & 4 & 4 \\
\hline
\end{tabular}

* White students are from families where the home language is either Afrikaans or English. The same applies to students of mixed race. Indian students are all from homes with parents who are third generation (and further) South Africans. Hence the indigenous Indian languages (Tamil, Urdu, Telegu, Hindi, Gujarate, Pukhtu, etc.) have long since died out and been replaced by English as the home language. The home languages of Black students are Isizulu, Isixhosa, Sotho and Siswate.

4 Chlidren 13-17 years of age. 


\section{Perceptions on role of parents}

Participants from school management teams and school governing body teams indicated that parents have financial obligations (buying school uniforms and stationery for their children, paying school fees). In addition, the participants felt that parents should also be committed to seeing to it that their children abide by the school's code of conduct, and support the school in its fundraising efforts. Regarding the multicultural nature of the schools in the study, a school governing body member stated that parental involvement should include '... representing and reflecting the socio-economic values of my community to ensure that the education and teaching is appropriate and relevant and that the management of the school is effective and sustainable. However, some of the parents who were interviewed, particularly those from poor communities, displayed a very limited understanding of what parental involvement entails, beyond basic obligations such as paying school fees and buying books and uniforms. Indian parents were also reluctant to become involved due to work commitments. It could be argued that this lack of consensus on what roles parents should play excludes the possibility of parents and schools reaching shared goals on parent involvement.

\section{Policy on parent involvement}

At all three schools, there is a lack of a written formal policy on parent involvement. Moreover principals do not see any need for such a policy. One of the principals argued that the booklet The Rights of Parents, which is given to learners on admission to the school, is sufficient. A school governing body member did, however, acknowledge that if there were a policy on parent involvement, more parents would become involved and much more could be done in upgrading the school resulting in more learning taking place. Another school governing body member expressed the view that in order to raise the standard of education parents need to know about activities taking place outside the classroom situation and be able to render help where possible. Even in unwritten existing policies, no allowances are made for parents coming from different areas, socio-economic backgrounds or diverse cultural and language groupings. Of concern is the view of one principal that 'It is not the school management team's job to get parents involved, it is the state's job.' If this is the viewpoint of the principal it is unlikely that anyone else in the school will be supported in initiating parental involvement and drawing up a policy to guide home-school partnerships. 


\section{Communication between school and home}

In all three schools, school meetings were held and participants gave views on the communication of parents with the school.

\section{Parent meetings}

Parent meetings seem to be the primary means of contact between parents and teachers at all three schools. Attendance by parents is, however, generally poor. A school manager expressed it as follows: 'You know, we get the parents of our bright learners more often coming to meetings. We don't want to see them, and we tell them this. We went to see parents of the learners who give us a hard time at school, but their parents don't come.' However, principals do not make any efforts to find out why these parents are not attending meetings and what can be done to better accommodate them. All meetings at all three schools are conducted in English. Judging by the responses of parents, it seems as if there are language problems that schools are not aware of. Moreover, responses from school management indicate that schools often label non-English speaking parents as 'uncooperative' and do not feel the need to provide translators during parent meetings. However, it needs to be noted that the schools have made an effort to hold parent meetings at times that suit the majority of parents.

\section{Written communication}

At all schools, letters are sent to parents in the form of newsletters, termend letters to inform them of forthcoming meetings, and circulars. Managers reported that funds for all forms of written communication are limited. One of the parents also complained that letters are often ineffective as schools have to rely on learners delivering the letters. Letters are sent to parents in English by all three schools. As is the case with school meetings, the sole use of English in written communication is a problem, as is captured by the words of one of the parent participants: 'Sometimes I tell my child to read for me, I can't read English nice. I don't know if he reads the truth or what.'

\section{Parent-school communication}

Managers and principals were of the opinion that no problem exists as school principals have an open door policy and are quite accessible to parents. However, once more the question of language was raised by parents. One Black parent mentioned a problem when she telephoned the school: '... The man who answered, he not understand what I'm saying. He say, speak English, speak English.' All school governing body members of one of the schools expressed 
the need for a Parent Support Committee in order to encourage parents of weak learners to communicate with the school regarding their children.

\section{Parents as decision-makers}

None of the school governing body members of any of the three schools reflect the racial composition of the schools - Black parents being grossly underrepresented. Since parents on the school governing bodies make decisions on behalf of the general parent body, it is necessary for them to possess certain skills and knowledge in order to have constructive input. This especially puts Black parents from poor and ill-educated backgrounds at a disadvantage. None of the school governing body members at School A have any training. One of them said: 'I have a Grade four education and I am willing to learn.' Unfortunately, none of the schools provide any training for school governors, once again arguing that it is 'the job of the state' to do so. Of the fifteen parents who were interviewed, only seven indicated that they knew who their school governing body members were.

\section{Giving parents support}

Many learners from the three schools in the study come from singleparent homes or live with their grandparents. Often, such learners are difficult to control and have many problems associated with poverty. It seems clear that many teachers are concerned about learners in these difficult economic times and in one case have started a feeding scheme paid for out of their own pockets. However, what seems to be lacking is the organised management of such initiatives. In this regard, School $\mathrm{C}$ has the advantage of having a social worker on their staff who can deal with some of the problems. However, it appears that parents also have problems that do not directly involve their children. For example, a school governing board member of School C remarked: 'Parents and staff often bring matters to me, for example, medical aid, getting a raise in income, school fees, uniform issues, et cetera. Such matters I take to the school governing body meetings.' School board governing bodies at Schools A and B indicated that parents have not approached them for assistance.

\section{Using parent volunteers}

All schools included in the study have used parent volunteers to some extent. For example, at School A the principal identified maintenance work, repairs 
and the running of the tuck shop as work carried out by parent volunteers. Upon questioning parents on their involvement in school activities, parents indicated that they would like to help but are too involved with their own lives.

\section{Accommodating cultural differences}

All schools strongly emphasised that their school had no reason to believe that racism is a problem at their respective schools. The governing body at each school maintained that parents of all cultural groups were encouraged to participate in school activities. Yet the medium of communication at all schools is solely English; suggesting that school managers have not made a significant effort to overcome language barriers, as they have not recognised it as such.

\section{Barriers to parental involvement}

The following barriers to parental involvement were mentioned by school managers, members of school governing bodies and parents:

- $\quad$ Apathy. Many parents are apathetic and do not seem to feel a need to become involved in their children's education.

- Transport. Traveling distances to schools and the lack of transport, have proved to be a problem at all the schools under study.

- $\quad$ Financial problems of schools and families. Parents are expected to contribute to finance and fundraising. As a result, poor parents especially keep their distance as they feel that if they become too involved at the school, they could be asked for additional financial contributions.

- Working parents. Many parents are not involved in school activities due to work commitments.

- Low self-esteem of parents. Many parents feel they cannot communicate adequately with the educators due to language barriers and poor education.

- $\quad$ Lack of knowledge. Many parents are ignorant as many issues pertaining to parental involvement in schools.

\section{Benefits of parental involvement}

All participants agreed that there are advantages to be derived from active parental involvement in schools. The benefits mentioned by the participants include:

- $\quad$ developing a sense of ownership and pride in the school; 
- morale building, which will have an uplifting effect upon the entire community;

- $\quad$ reduction in costs;

- $\quad$ improved learner behaviour;

- $\quad$ parent awareness of school matters;

- $\quad$ building a sense of community;

- $\quad$ improving academic achievement.

In spite of this awareness of the benefits associated with parent involvement, very little seems to have been done by the schools to encourage parent-school collaboration.

\section{Discussion}

The low level of meaningful contact of the schools with parents, especially Black parents, has led to some teachers and principals to conclude that such parents lack sufficient interest in their children's education and do not want to work with the schools. The viewpoint is manifested in interviews conducted in all three schools. Moreover, in all interviews it was stressed that such parents are particularly apathetic regarding issues related to the education of their children. These perceptions are not unique to South Africa, as international research indicates that teachers are less likely to know the parents of children who are culturally different from their own background and to label such parents as 'uninterested' or 'apathetic' (Epstein \& Dauber, 1993, p. 289). In South Africa the situation is exacerbated by the fact that few teachers have been taught how to deal with diversity, both in and out of the classroom.

The research has also shown that school managers have low expectations of parents, particularly non-English speaking parents. They expect that certain groups of parents will not attend meetings and therefore do not cater for the needs of non-English speaking parents. The responses given by principals and teachers show that they possess limited understanding of the concept of parental involvement, and are therefore unable to establish a comprehensive parental involvement programme, whereby parents from the different cultural groups can participate. This is unfortunate as a well-designed comprehensive parental involvement programme can offer a variety of ways in which parents from all walks of life can become involved in the education of their children (Van Wyk, 2010, p. 217).

There is an extant lack of an organisational structure to deal with parent involvement. For example, none of the schools have a parent support team. 
Similarly, there is an absence of a school policy on parent involvement, which international research has shown to be the most important determinant of effective home-school programmes (Epstein \& Sanders, 2000, p. 289). School management also has the perception that parents' low socio-economic status has a detrimental effect on their involvement in school matters. In addition, schools in poorer communities tend to make more contact with parents regarding the problems their children are having at school, rather than making frequent contact with such parents about the positive accomplishments of their children (Van Wyk \& Lemmer, 2009, p. 180).

Restricted opportunities for interaction between parents and schools exist, i.e. lack of time and a language barrier (in the case of parents with limited English speaking abilities) are inter alia to blame for this. Home-school communication is not always fruitful. One major reason for this is the lack of accommodation of parents who are not proficient in English. This is unfortunate as there is always a potential of problems arising between parents and educators in schools with large numbers of linguistically diverse learners, with differences in ethnicity, educational levels and social class.

Judging by the findings of this research it seems, as if the words of Chrispeels (1991, p. 371) need to be repeated, i.e. that when it comes to parent involvement, schools tend to direct their efforts at 'fixing parents rather than altering school structures and practices'. With this in mind, a few recommendations on ways of improving the management of parental involvement in multicultural schools are offered.

\section{Recommendations}

One of the first steps in creating home-school partnerships in multicultural schools is to recognise that the strength of the school lies in the differences families bring to the school (Van Wyk \& Lemmer, 2009, p. 166). Schools therefore need to provide a warm welcome to all parents, which includes taking into account the different languages, cultures, traditions, and faiths of the parent body. This includes the acknowledgement that learners and parents of cultures other than the dominant culture of the school deserve respect. This should, inter alia, include strengthening communication strategies which take into account the linguistic differences of the community.

Related to this is the need for schools to acknowledge that all parents are interested in the welfare of their children. Where parents may be absent from most school activities, the school needs to determine the reason for this, instead of presuming that certain groups of parents do not have the interest of 
their children at heart. Extensive research has shown this to be a fallacy and that most parents are interested in their children's schooling and want them to succeed (Epstein, 2001; Van Wyk \& Lemmer, 2009).

Traditional views on parental involvement limit rather than increase the potential for educators and parents to work together. In other words, if there is a lack of opportunities for parents to become involved in the education of their children, few will make the effort to do so. However, Epstein et al. (1997) note that research illustrates that when parental involvement is viewed broadly, it is possible to involve virtually all parents in the education of their children, including parents of low income status and those who are illiterate or have limited proficiency in English. It is therefore recommended that schools do research on the institution of a comprehensive parental involvement programme. One example of such a programme is that of Epstein, which was discussed at the beginning of this article.

Research also shows that planning largely determines the potential and limitations of home-school relations (Michael, 2004, p. 35). Such planning includes the following sub-tasks: determining goals, policy making, problem solving and decision making (Van der Westhuizen, 1995, p. 410). At the heart of these activities lies the leadership role of the principal, as research clearly shows that principals are key agents in bringing about change in schools (Steyn, 2002, p. 115). This means that the principal together with his/her management team should determine the goals of parental involvement programmes, develop a written policy on parental involvement and institute a structure tasked with organising parental involvement in the school. One of the benefits of a written policy is that it ensures a 'shared understanding' of what form parental involvement should take. Obviously, parents should be included in determining such a policy.

Another way of ensuring that parental involvement is effectively managed is to establish a team specifically tasked with improving or establishing parental involvement at the school. Instituting an Action Team consisting of parents, teachers and learners (in secondary schools), as described by Epstein (1997), is recommended. In the case of multicultural schools, care must be taken that the Action Team represents the racial composition of the parent body. The principal and management team should also ensure that all parental involvement programmes are evaluated regularly and that steps suggested to address any problems are implemented.

Unfortunately, initial teacher training programmes seldom include the skills needed for working with parents. Such skills are even more important when the majority of parents in the school belong to a different language, ethnic 
or cultural group than the teacher. This lack of knowledge makes it difficult for teachers and the management team to form effective partnerships with parents. It is therefore important for teachers to be trained to work with all kinds of parents, including those from diverse cultural backgrounds, in order to form a true partnership between the home and school which will ultimately benefit all students.

\section{Conclusion}

Advocates of multicultural education encourage schools to maintain a strong relationship with families and their communities (Sleeter \& Grant, 2007, p. 446). This should include cooperation, communication and understanding between teachers and parents and the institution of an effective comprehensive parental involvement programme. This is important as the family is the most immediate and perhaps the most influential system affecting the child (Walsh \& Williams, 1997, p. xi). However, ultimately the success of all parental involvement programmes within diverse school communities will depend on how well the programme matches up with the needs of all parents and caregivers. This means that if a school is sincere in providing education that will lead to the success of all learners, it would do well to involve all parents in this endeavour.

\section{References}

Banks, J. A., \& Banks, C. A. M. (1997). Multicultural education: Issues and Perspectives. Boston: Allyn and Bacon.

Bastiani, J. (1996). Parent involvement. Paper presented at a seminar on Parent Involvement, 26

March 1996, Rand Afrikaans University.

Bogdan, R. C., \& Biklen, S. K. (1992). Qualitative Research for Education: An Introduction to Theory and Method. Boston: Allyn and Bacon.

Botha, R. J. (2000). Managing the school as an organization. Unisa Tutorial letter 104/2000 for $M E D E M$ 5-R. Pretoria: University of South Africa.

Castagno, A. E. (2009). Making sense of multicultural education: A synthesis of the various typologies found in the literature. Multicultural Perspectives, 11(1), 43-48.

Chavkin, N. F. (1989). A multicultural perspective on parent achievement: implications for policy and practice. Education Spring, 109(3), 276-285.

Chavkin, N. F. (1993). Families and Schools in a Pluralistic Society. Albany: State University of New York.

Cohen, L., \& Manion, L. (2000). Research Methods in Education. London: Routledge.

Chrispeels, J. H. (1991). District leadership in parent involvement: Policies and actions in San Diego. 
Phi Delta Kappan, January, 367-371.

De Vos, A. S. (1998). Research at Grassroots: A primer for the caring profession. Pretoria: JL van Schaik. Epstein, J. L. (1995a). School, family, community partnerships: caring for the children we share. Phi Delta Kappan, May, 701-712.

Epstein, J. L. (1995b). Perspectives and previews on research and policy for school, family and community partnerships. In A. Booth \& J. Dunn (Eds.), Family-school links: How do they effect educational outcomes? Hillside, NJ: Erlbaum.

Epstein, J. L. (2001). School, Family and Community Partnerships: Preparing educators and improving schools. USA: Westview Press.

Epstein, L., \& Dauber, S. L. (1993). Parents' attitudes and practices of involvement in inner-city elementary and middle schools. In N. Chavkin (Ed.), Families and Schools in a Pluralistic Society. Albany, NY: State University of New York.

Epstein, J. L., \& Sanders, M. G. (2000). Connecting home, school and community: New directions for social research. In M. Hallinan (Ed.), Handbook of the Sociology of Education. New York: Kluwer. Haberman, M. (1992). Creating community contexts that educate: an agenda for improving education in inner cities. In L. Kaplan (Ed.), Education and the Family. Massachusetts: Allyn \& Bacon.

Henderson, A. T., \& Mapp, K. (2002). A New Wave of Evidence: The impact of school, family, and community connections on student achievement. Austin: Southwest Educational Laboratory.

Hester, H. (1989). Start at home to improve home school relations. NASSP Bulletin, January, 23-27.

Hoberg, S. M. (1999). Research Methodology. UNISA: Study Guide 2 for MEDEM2-R. Pretoria:

University of South Africa.

Jones, L. T., \& Blendinger, J. (1994). New beginnings: Preparing future teachers to work with diverse families. Action in Teacher Education, 16(3), 79-86.

Lemmer, E. M. (1992). Quality research methods in education. South African Journal of Education, 12(3), 292-295.

Lemmer, E. M. (2000). The Epstein Model of Family school partnership: teachers' experiences in South African schools. Educare, 29(1\&2), 60-75.

Lemmer, E. M. (2007). Parental involvement in teacher education in South Africa. 6th International conference of the European Research Network about Parents in Education (ERNAPE). Nicosia, Cyprus. August 29-31.

Mda, T. (1999). Education for divesity. In E. M. Lemmer (Ed.), Contemporary Education: Global issues and trends. Sandton: Heinemann.

Meier, C., Lemmer, E., \& Van Wyk, N. (2006). Multicultural Education: An educator's manual.

Pretoria: Van Schaik.

Michael, S. (2004). The Management of Parental Involvement in Multicultural Schools in the Umlazi

District. Unpublished DEd thesis. Pretoria: University of South Africa.

Neumann, W. L. (1999). Social Research Methods: Qualitative and Quantitative approaches. Needham Heights: Allyn and Bacon. 
Nkomo, M., Chisholm, L., \& McKinney, C. (2004). Through the eye of the school - in pursuit of social integration. In M. Nkomo, C. McKinney \& L. Chisholm (Eds.), Reflections on school integration. Colloquium proceedings. Cape Town: HSRC.

Organisation for Economic Co-operation and Development (OECD) (2008). Reviews of national Policies for Education: South Africa. Brussels: OCED.

Pearson, N. (1990). Parent involvement within the school. Education Canada, Autumn, 14-17.

Ravn, B. (2003). Cultural and political divergences in approaches to cooperation between home, school and local society in Europe. In S. Castelli, M. Mendel \& B. Ravn (Eds.), Schools, families and community partnership in a world of differences and changes. Gdansk: Universytet Gdanski.

Sampson, E. E. (1999). Dealing with Differences: An introduction to the social psychology of prejudice.

Albany: State University of New York Press.

Schumacher, S., \& McMillan, J. H. (1997). Research in Education: A conceptual introduction. New York: Harper Collins.

Squelch, J., \& Lemmer, E. (1994). Eight Keys to Effective School Management in South Africa. Halfway House: Southem.

Squelch, J. (1996). Parent Participation: How to help your child succeed in school. Pretoria: Acacia Books.

Sleeter, C. E., \& Grant, C. A. (2007). Making Choices for Multicultural Education. New York: Wiley. Soudien, C. (2004). Constituting the class: an analysis of the process of 'integration' in South African schools. In L. Chisholm (Ed.), Changing class. Education and social change in post-apartheid South Africa. Cape Town: HSRC.

Smit, B. (2010). Doing research in Comparative Education. In E. Lemmer \& N. Van Wyk (Eds.), Themes in South African education. Cape Town: Heinemann.

Steyn, G. M. (2002). School management in South Africa. In N. Van Wyk \& E. Lemmer (Eds.), Transforming education: The South African experience. New York: Nova Science.

Van der Linde, N. (1997). Managing multicultural schools. Unisa manual for EDE MCI-E. Pretoria: University of South Africa.

Van der Westhuizen, P. C. (1995). Effective Educational Management. Pretoria: Kagiso Tertiary. Van Wyk, N., \& Lemmer, E. (2009). Organising parent involvement in South African Schools. Cape Town: Juta.

Van Wyk, N. (2010). Theories, policies and practices of parent involvement in education. In E. Lemmer \& N. Van Wyk (Eds.), Themes in South African education. Cape Town: Heinemann. Williams, P. L., \& Chavkin, N. F. (1989). Essential elements of strong parent involvement programs. Educational Leadership, $47(2)$.

Walsh, M. W., \& Williams, G. R. (Eds.) (1997). Schools and Family Therapy. Springfield: Charles C Thomas.

Wolhuter, C. C. (1998). Spektroskopie van die Suid-Afrikaanse onderwysstelsel binne die internasionale ry van nasionale onderwysstelsels. Suid-Afrikaanse Tydskrif vir Opvoedkunde. 


\section{Appendix 1. \\ The Focus Group Discussion Schedule: \\ School Management Teams}

1. Biographic information of members:
a) race group
b) age
c) gender
d) number of years in present position
e) language spoken
f) place of residence

2. The nature of parental involvement in the school

- What are the basic obligations regarding the education of their children?

- What are the basic obligations of the school in this regard?

- In what ways are parents involved in the school?

- Does the school have a written or verbal policy of involving parents?

- What are the opinions of staff at this school about working closely with parents?

3. Communication with parents

- In what way does the school communicate with parents?

- Where and when are parent meetings held? How does this suit the needs of all parents?

- What measures are in place to ensure effective communication with parents during parent evenings?

- What language(s) are used in written communication with parents?

- Under what circumstances are individual meetings with parents held?

- What opportunities are provided for parents to communicate with the school?

- Generally, who makes use of these opportunities?

4. Parent support of learning at home

- What is the homework policy of the school?

- In what way have parents been informed of this?

- How have parents been assisted to support learners at home? 
5. Parents as decision makers

- In what way does the school governing body reflect the racial composition of the school?

- How are parents included in decision-making at this school?

- How do you ensure that the opinion of all racial groups is reflected in the decisions you take?

6. Parent volunteers

- In what way are parent volunteers used in this school?

- Which parents generally offer to work at the school? In what capacity?

- How are volunteers invited?

7. Barriers to parent involvement

- What factors act as barriers to effective parental involvement in the school?

- In what ways has the school attempted to rectify the problem?

- Do you feel that there are negative aspects to parent involvement?

8. Advantages and problems

- What would you consider to be the advantages of parent involvement?

9. Staff training

- Have teachers been trained to implement parental involvement in this school?

- Have teachers been trained to work with children and parents from different social groups? 


\section{Appendix 2. \\ The Focus Group Discussion Schedule: School Governing Bodies}

1. Biographic details of members:

a) race

b) age

c) gender

d) highest level of education

e) place of residence

f) language spoken

2. What does parental involvement mean to you?

3. As a parent representative, discuss some of your efforts to gain parent support.

4. You are involved in school governance, making decisions on behalf of parents. How equipped are you in terms of knowledge, skills and values?

5. Describe your experiences as a parent during school visits. What did you like? What did you not like? Why?

6. Which aspects/arenas of school matters do you control or manage? Assess the effectiveness of your involvement.

7. Problems experienced by parents: How often are you consulted as a school governing body member to help with issues? What are some of the issues brought to you by parents?

8. Are racial issues ever discussed at School Government Bodies meetings? Give examples.

9. How accessible are you to the general parent body? Do you particularly assist members of your own race group/cultural group? Have you assisted parents other than your own race group?

10. Reflect on your school situation. Discuss the school's attempts in meeting the needs of a multicultural community.

11. What are your feelings regarding the establishing of a Parent Support Committee? What are some of the aspects that such a committee could assist in?

12. What are some of the things you are happy/unhappy about with regard to parent involvement? How can it be improved? 


\section{Appendix 3. The Focus Group Discussion Schedule: Parents}

1. Biographic details of participants:
a) race
b) age
c) place of residence
d) language spoken
e) marital status

2. What are your feelings regarding parental involvement as a parent of a secondary school learner?

3. As a parent, what basic obligations do you meet?

4. What activities have you been involved in at your child's school?

5. Describe the school climate on your visits to school.

6. Assess the management of learner activities/programs involving parents.

7. Discuss problems experienced with the school.

8. Describe some efforts made by the school/SGB to get you involved.

9. When have you been asked to visit? How successful was the visit? Did you wait to be attended to? Where did you meet the person who asked to see you? Were you satisfied?

10. What can the school do to facilitate parental involvement and make it more effective?

11. What is the school presently doing to have parents involved?

12. Which areas or aspects of school matters would you like to be involved in?

13. Respect for parents by school staff members. Discuss.

14. Teacher attitudes towards parent involvement. Discuss your experiences.

15. School management of parent involvement. Discuss.

16. When have you communicated with the school other than the school contacting you?

17. Discuss your feelings with regard to a Parent Management Team.

18. Communication strategies with parents. Are they acceptable? Have you had any problems? Are they effective?

19. Frequency of newsletters? Assess content in terms of language used. Is it fully understood? What problems have you or other parents you 
know experienced regarding information sent to you?

20. With regard to activities at school, who generally attends? How many parents attend?

21. How are parent complaints handled?

22. What literature is given to parents other than term newsletters or learner reports?

23. Volunteers. Are parents volunteering in any position at school? Have you considered? Discuss.

24. A school's visiting policy. Does one exist? Is it acceptable/unacceptable? Discuss.

25. Your relationship with the school's governing body. Do you know who the members are? How effective is the school governing body? Have you had any problems that you have taken to them? Discuss.

26. Describe your relationship with the school principal. Have you had personal contact with him/her? What are your feelings regarding his/her leadership style? Are parents' input respected by the school principal and management team?

27. What are your recommendations to improve parent involvement? 


\section{Biographical note}

CC WolHuter studied at the University of Johannesburg, the University of Pretoria, the University of South Africa and the University of Stellenbosch. His doctorate was awarded in Comparative Education at the University of Stellenbosch. He is a former junior lecturer of History of Education and Comparative Education at the University of Pretoria and a former senior lecturer at the University of Zululand. He is currently Comparative Education professor at North-West University, Potchefstroom Campus, South Africa. For the 2012 winter semester he is visiting professor of Comparative and International Education at Brock University, Canada. He is the author of several books and articles in Comparative Education and History of Education and was co-editor of the book Comparative Education at Universities Worldwide published by the World Council of Comparative Education Societies in 2008; and of the encyclopedia International Handbook on Teacher Education published in 2010. He is currently president of SACHES, Southern African Comparative and History of Education Society.

Noleen VAN WYK is Emeritus Professor at the University of South Africa. Before retiring she was Chair of the Department of Educational Studies at the same university. Her lecturing responsibilities included tuition of doctoral, masters and honours degree students in the fields of comparative education, policy studies, education management and parental involvement. Professor van Wyk has published extensively and has presented papers at conferences in, among others, the United Kingdom, Central Europe, Canada, Cyprus and China. She is currently involved in academic writing and assisting master's degree students with their research projects.

Sathiapama Michael qualified as a teacher with a Bachelor of Paedogogics Degree at the University of Kwa-Zulu Natal. She obtained a Honours Degree, a Further Diploma in Education specialising in multicultural education, a Postgraduate Diploma in Education Management and a Masters in Education Management Degree at the University of South Africa. Michael presently teaches English Home Language at a multicultural urban high school in Kwa-Zulu Natal. She has been teaching at various multicultural schools for almost twenty years. Due to her extensive practical experience in the field of teaching she has developed a keen interest in establishing parent involvement in schools in our newly established multicultural democracy. 